\title{
Effect of different grades of concrete on rc framed multi- storied building
}

\author{
Vemundla Ramesh $^{1}$, Chitla Raju ${ }^{2-}$ \\ ${ }^{1}$ Assistant Professor in Civil Engineering, Gokaraju Rangaraju Institute of Engineering and Technology, Bachupally, Hyderabad, \\ Telangana, India-500090 \\ ${ }^{2}$ PG student in Civil Engineering, University College of Engineering, Osmania University, Amberpet, Hyderabad, Telangana, \\ India-500007
}

\begin{abstract}
Due to the application of advanced material technology, concrete with high compressive strength is currently produced and used in many countries. This type of concrete can be produced by micro-silica and superplasticizers as well as applying good quality control procedures. The use of high-strength concrete (HSC) in building construction is becoming popular because it has many advantages such as increased strength and stiffness, reduced size of concrete sections, improved resistance to creep and drying shrinkage, and material durability. Therefore we can use high strength concrete (HSC) in columns and normal strength concrete (NSC) for beams \& floor sections. Thus this study will investigate the performance of 8 storey tall buildings in ZoneIV for medium grade soil with varying high strength concrete (HSC) normal strength concrete (NSC) subjected to far-field ground motions scaled to collapse of the structure using varying grades (M20, M25, M30, M35, M40, and M50) of concrete strength subjected to seismic ground motions scaled to collapse of the structure using a linear static method and this will be achieved through analytical modeling and analysis using ETABS2018 software.
\end{abstract}

\section{Introduction}

As reinforced concrete frames respond to strong ground motion, it is likely that elements of the frame will have nonlinear behavior. The elements that yield may experience large deformations that contribute to increased localized story deformations in the frame. This is especially true when columns undergo inelastic deformations, as the drift at the story with yielding columns may magnify in part caused by the secondary effects of the axial loads. In addition, $1 \mathrm{t}$ is important to minimize the occurrence of yielding in concrete columns, especially near the base of the frame, because of difficulties encountered for detailing these elements for ductile response under high axial loads. If yielding in the columns can be eliminated, then the building will tend to respond with a stiff spine and drift will be evenly distributed over the height of the structure. This leads to smaller story drifts (the relative drift between two consecutive floor levels) and less subsequent damage in the lower portion of the frame where columns are subjected to high axial loads.

\section{Significance of the study}

All the structural elements in the buildings i.e. beams, columns \& slabs are needed to resist all kinds of the loads acting on them. Even if a single column is failed in building that leads to a drastic effect in terms of life \& economy, Although we design our building by taking strong column weak beam criteria (SCWB), In case of high rise buildings due to wind loads and in case of low rise \& medium rise buildings 
due to earthquake loads plastic hinges may develop in the columns before the beams so that leads to failure of columns. Therefore by using different grades of concrete in reinforced concrete building frames we increase the axial, flexural \& shear characteristics of columns to carry heavy loads coming from the surrounding beams and slabs.

\section{Objective and scope of the work}

The objective of the present study is to evaluate the effect of different grades of concrete criterion on Rc Frame (moment-resisting frame) building by using linear, nonlinear methods and quantify the economical, Storey displacements \& Storey drifts as per IS codes. To determine displacement, inter-storey drifts of Rc Framed Structure for different grades of concrete. The study will investigate the performance of tall buildings with varying grades of concrete strength subjected to seismic ground motions scaled to collapse of the structure using a linear dynamic analysis approach and This will be achieved through analytical modeling and analyses using ETABS software. The scope of the project is limited to reinforced concrete framed structures designed for dead loads (DL), live loads (LL), wind loads (WL) \& seismic loads (EL). The structure is evaluated in accordance with the codal provisions. The analysis is done for 8 storey structure and is analyzed for different grades of concrete for beams and columns. The same building is analyzed and designed for different values of concrete strengths M20, M25, M30, M40, M50.

\section{Structural Modelling}

The building is evaluated and modeled using ETABS2017. The structural components are modeled taking into consideration the various aspects of the building details. Common elements in reinforcedconcrete construction include frames i.e. beams and columns. The building models are generated in the integrated building analysis and design software ETABS 2017. Beams and columns are modeled using three-dimensional (3D) frame elements, while the slabs are defined as rigid diaphragms. The cracked section properties of both beams and columns are taken from practical field cross-sections used in India. Both dead and live loads and wind loads are assigned to the building models according to IS 875 Part 1 (1987) and IS 875 Part 2 (1987) and IS 875 Part 2 (2015), respectively. All the buildings are designed following the provisions of the relevant Indian standards (IS 456 2000; IS 1893 Part I 2016; IS 13920 (2016). Local subsoil conditions are represented by soil type II (i.e., medium soil/rock) following the soil classification defended by Indian code IS 1893 Part 1(2016) \& for Zone IV, $\mathrm{k} 3=1, \mathrm{k} 2=1$ with wind speed of $44 \mathrm{~m} / \mathrm{s}, \mathrm{Cpe}=0.8$ (external Coefficient of pressure) $\mathrm{Cpi}=0.5$ (Internal Coefficient of pressure) wind load applied of assigned diaphragm

Available market-based structural crosssectional sizes are used for both columns and beams. In our Analysis C230X600, C300x525, C230x600 \& $\mathrm{C} 230 \mathrm{X} 525$ are used with respective grades of $\mathrm{C} 30$, C25, C40 \& C50. For beams FB 230x500 used in the case of failure of $\mathrm{FB} 230 \times 500$, they upgraded to FB300x525(FB-Floor beam, C-Column).

Table 1. Modeling Grid data: X-axis

\begin{tabular}{|c|c|}
\hline Grid Number & Distance(feet) \\
\hline 1 & 9.5 \\
\hline 2 & 16.5 \\
\hline 3 & 7.75 \\
\hline 4 & 7 \\
\hline 5 & 2.5 \\
\hline 6 & 16.5 \\
\hline 7 & 0 \\
\hline
\end{tabular}

Table 2. Modeling Grid data: Y-axis

\begin{tabular}{|c|c|}
\hline Grid & Distance(feet) \\
\hline A & 13 \\
\hline B & 15.25 \\
\hline C & 14.5 \\
\hline D & 5.75 \\
\hline E & 13 \\
\hline F & 15.25 \\
\hline G & 14.5 \\
\hline
\end{tabular}


Table 3. Storey data for different floors

\begin{tabular}{|c|c|c|c|c|}
\hline $\begin{array}{c}\text { Storey } \\
\text { number }\end{array}$ & $\begin{array}{c}\text { Height } \\
\text { (Feet) }\end{array}$ & $\begin{array}{c}\text { Cumulati } \\
\text { ve } \\
\text { height(fe } \\
\text { et) }\end{array}$ & $\begin{array}{c}\text { Master } \\
\text { storey }\end{array}$ & $\begin{array}{c}\text { Similar } \\
\text { storeys }\end{array}$ \\
\hline 8 & 10.5 & 87.5 & NO & 2 \\
\hline 7 & 10.5 & 77 & NO & 2 \\
\hline 6 & 10.5 & 66.5 & NO & 2 \\
\hline 5 & 10.5 & 56 & NO & 2 \\
\hline 4 & 10.5 & 45.5 & NO & 2 \\
\hline 3 & 10.5 & 35 & NO & 2 \\
\hline 2 & 10.5 & 24.5 & YES & None \\
\hline 1 & 10 & 14 & NO & None \\
\hline Plinth & 4 & 4 & NO & None \\
\hline FDN* & 0 & 0 & NO & None \\
\hline
\end{tabular}

*FDN-Foundation

\section{Results and discussions}

By using different grades of concrete in 8 storey framed buildings we can conclude that when the grade of concrete increases in the columns there is a decrease in cross-section sizes \& lateral storey displacements.

Table 4. Maximum storey Displacement in $\mathbf{m m}$

\begin{tabular}{|c|c|c|c|}
\hline $\begin{array}{c}\text { Grade } \\
\text { kN/Cum }\end{array}$ & Column & $\begin{array}{c}\text { Load } \\
\text { Type }\end{array}$ & $\begin{array}{c}\text { Displacement } \\
\text { mm }\end{array}$ \\
\hline M25 & C230X600 & EQX* & 23.10 \\
\hline M25 & C230X600 & EQY\# & 25.72 \\
\hline M30 & C300X525 & EQX & 23.8 \\
\hline M30 & C300X525 & EQY & 21.43 \\
\hline M40 & C230X600 & EQX & 22.64 \\
\hline
\end{tabular}

\begin{tabular}{|c|c|c|c|}
\hline M40 & C230X600 & EQY & 24.71 \\
\hline M50 & C230X525 & EQX & 24.2 \\
\hline M50 & C230X525 & EQY & 25.9 \\
\hline
\end{tabular}

EQX*-Siesmic force in X-direction,

EQY\#-Siesmic force in Y-direction

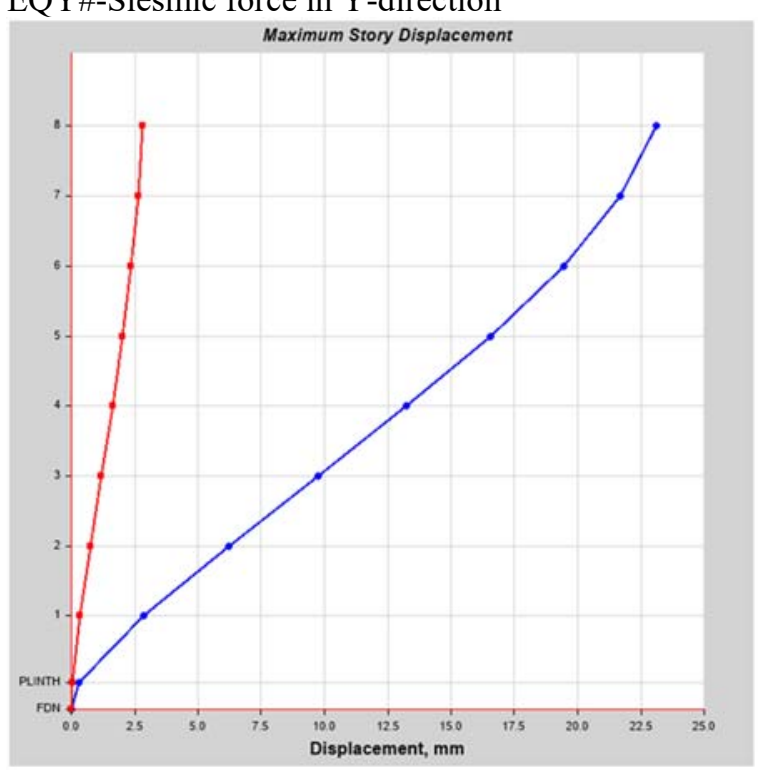

Figure-1: EQX Storey Displacements C-230x600 (C30 25)

Table 5. Storey response values

\begin{tabular}{|c|c|c|c|c|}
\hline Storey & $\begin{array}{c}\text { Elevat } \\
\text { ion(m) }\end{array}$ & Location & $\begin{array}{l}\text { X- } \\
\text { directio } \\
\mathbf{n ( m m )}\end{array}$ & $\begin{array}{l}\text { Y- } \\
\text { directio } \\
\mathbf{n ( m m )}\end{array}$ \\
\hline 8 & 26.67 & Top & 23.10 & 2.79 \\
\hline 7 & 23.46 & Top & 21.69 & 2.63 \\
\hline 6 & 20.26 & Top & 16.44 & 2.36 \\
\hline 5 & 17.06 & Top & 16.55 & 2.36 \\
\hline 4 & 13.86 & Top & 13.25 & 2.02 \\
\hline 3 & 10.66 & Top & 9.75 & 1.62 \\
\hline 2 & 7.54 & Top & 6.23 & 1.19 \\
\hline 1 & 4.26 & Top & 2.85 & 0.34 \\
\hline PLIN & 1.21 & Top & 0.31 & 0.02 \\
\hline TH & & & & \\
\hline
\end{tabular}




\begin{tabular}{|l|l|l|l|l|}
\hline FDN* & 0 & Top & 0 & 0 \\
\hline
\end{tabular}

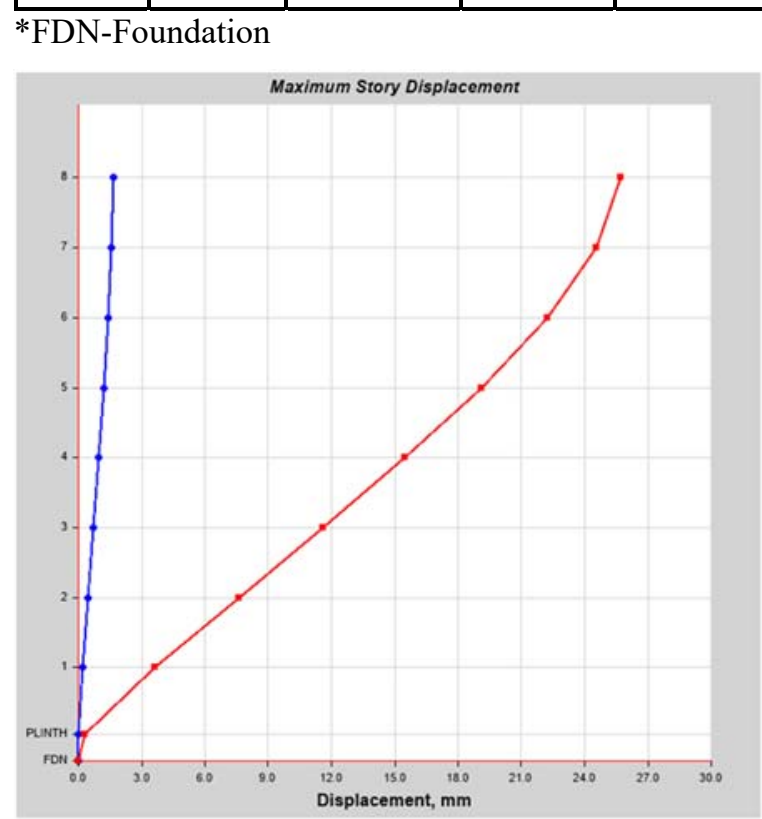

Figure-2: EQY Storey Displacements C-230x600 (C30 25)

Table 6. Storey response values

\begin{tabular}{|c|c|c|c|c|}
\hline Storey & $\begin{array}{l}\text { Elevat } \\
\text { ion }(m)\end{array}$ & Location & $\begin{array}{l}X- \\
\text { directio } \\
\text { n(mm) }\end{array}$ & $\begin{array}{l}Y- \\
\text { directio } \\
\text { n(mm) }\end{array}$ \\
\hline 8 & 26.67 & Top & 1.67 & 25.72 \\
\hline 7 & 23.46 & Top & 1.57 & 24.54 \\
\hline 6 & 20.26 & Top & 1.4 & 22.22 \\
\hline 5 & 17.06 & Top & 1.2 & 19.11 \\
\hline 4 & 13.86 & Top & 0.97 & 15.49 \\
\hline 3 & 10.66 & Top & 0.71 & 11.59 \\
\hline 2 & 7.54 & Top & 0.46 & 7.59 \\
\hline 1 & 4.26 & Top & 0.21 & 3.6 \\
\hline $\begin{array}{c}\text { PLIN } \\
\text { TH }\end{array}$ & 1.21 & Top & 0.02 & 0.29 \\
\hline FDN* & 0 & Top & 0 & 0 \\
\hline
\end{tabular}

*FDN-Foundation

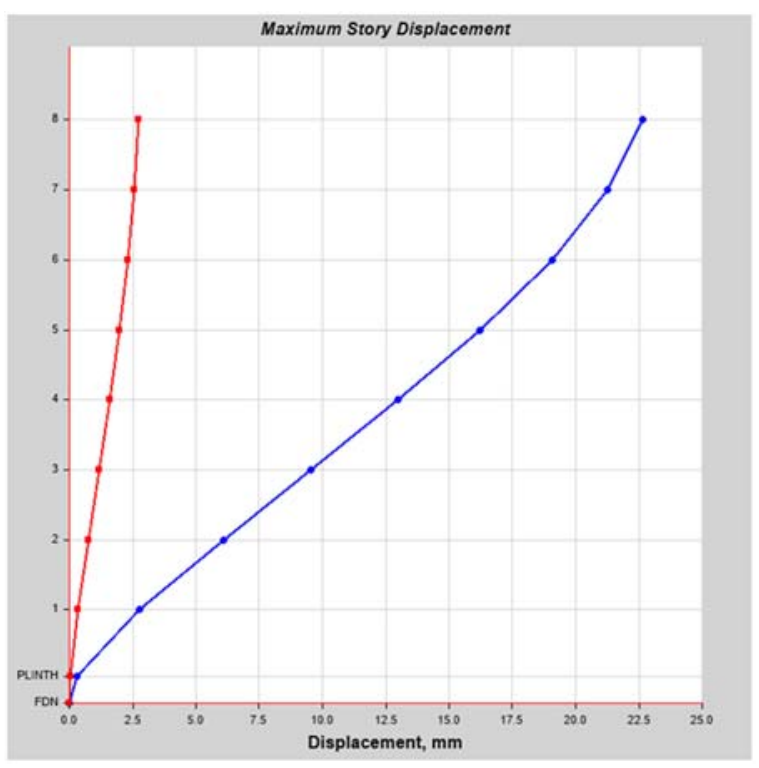

Figure-3: EQX Storey Displacements C-230x600 (C40 25)

Table 7. Storey response values

\begin{tabular}{|c|c|c|c|c|}
\hline Storey & $\begin{array}{l}\text { Elevat } \\
\text { ion(m) }\end{array}$ & Location & $\begin{array}{l}X- \\
\text { directio } \\
\text { n(mm) }\end{array}$ & $\begin{array}{l}\text { Y- } \\
\text { directio } \\
\text { n(mm) }\end{array}$ \\
\hline 8 & 26.67 & Top & 22.64 & 2.72 \\
\hline 7 & 23.46 & Top & 21.26 & 2.57 \\
\hline 6 & 20.26 & Top & 19.06 & 2.30 \\
\hline 5 & 17.06 & Top & 16.23 & 1.96 \\
\hline 4 & 13.86 & Top & 12.90 & 1.58 \\
\hline 3 & 10.66 & Top & 9.56 & 1.16 \\
\hline 2 & 7.54 & Top & 6.09 & 0.74 \\
\hline 1 & 4.26 & Top & 2.77 & 0.33 \\
\hline $\begin{array}{c}\text { PLIN } \\
\text { TH }\end{array}$ & 1.21 & Top & 0.30 & 0.02 \\
\hline FDN* & 0 & Top & 0 & 0 \\
\hline
\end{tabular}

*FDN-Foundation 


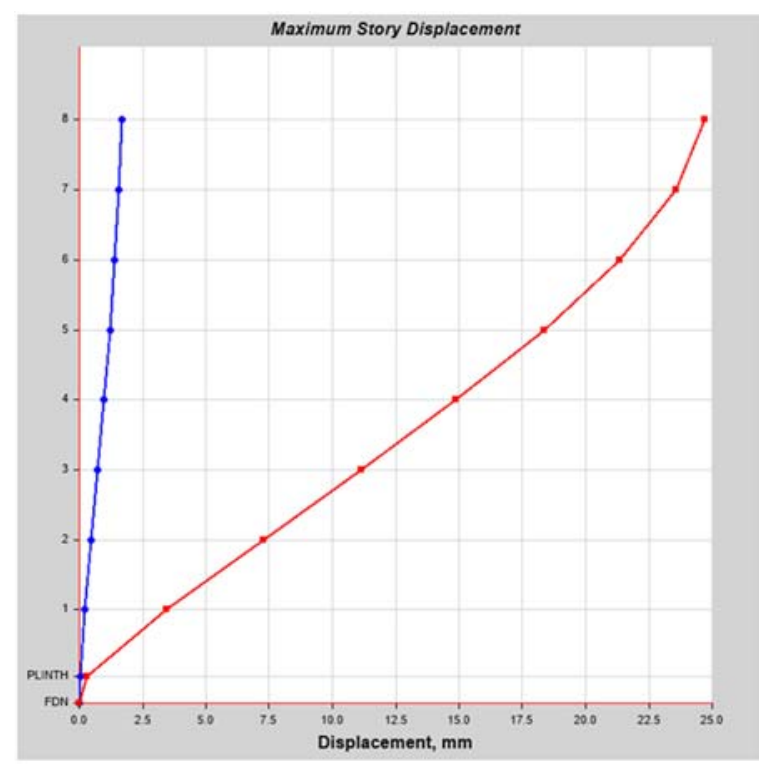

Figure-4: EQY Storey Displacements C-230x600 (C40 25)

Table 8. Storey response values

\begin{tabular}{|c|c|c|c|c|}
\hline Storey & $\begin{array}{l}\text { Elevat } \\
\operatorname{ion}(m)\end{array}$ & Location & $\begin{array}{l}X- \\
\text { directio } \\
\text { n(mm) }\end{array}$ & $\begin{array}{l}\text { Y- } \\
\text { directio } \\
\text { n(mm) }\end{array}$ \\
\hline 8 & 26.67 & Top & 23.10 & 2.79 \\
\hline 7 & 23.46 & Top & 21.69 & 2.63 \\
\hline 6 & 20.26 & Top & 16.44 & 2.36 \\
\hline 5 & 17.06 & Top & 16.55 & 2.36 \\
\hline 4 & 13.86 & Top & 13.25 & 2.02 \\
\hline 3 & 10.66 & Top & 9.75 & 1.62 \\
\hline 2 & 7.54 & Top & 6.23 & 1.19 \\
\hline 1 & 4.26 & Top & 2.85 & 0.34 \\
\hline $\begin{array}{c}\text { PLIN } \\
\text { TH }\end{array}$ & 1.21 & Top & 0.31 & 0.02 \\
\hline FDN* & 0 & Top & 0 & 0 \\
\hline
\end{tabular}

*FDN-Foundation

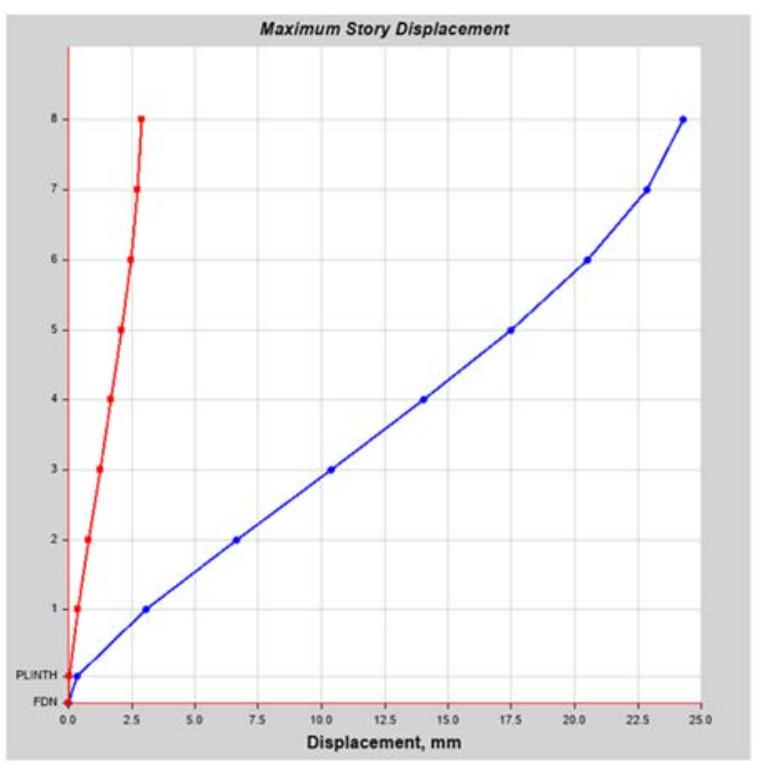

Figure-5: EQX Storey Displacements C-230x525 (C-50 25)

Table 9. Storey response values

\begin{tabular}{|c|c|c|c|c|}
\hline Storey & $\begin{array}{l}\text { Elevat } \\
\text { ion(m) }\end{array}$ & Location & $\begin{array}{l}X- \\
\text { directio } \\
\text { n(mm) }\end{array}$ & $\begin{array}{l}\text { Y- } \\
\text { directio } \\
\text { n(mm) }\end{array}$ \\
\hline 8 & 26.67 & Top & 24.28 & 2.90 \\
\hline 7 & 23.46 & Top & 22.86 & 2.74 \\
\hline 6 & 20.26 & Top & 20.52 & 2.46 \\
\hline 5 & 17.06 & Top & 17.49 & 2.10 \\
\hline 4 & 13.86 & Top & 14.00 & 1.69 \\
\hline 3 & 10.66 & Top & 10.37 & 1.25 \\
\hline 2 & 7.54 & Top & 6.66 & 0.80 \\
\hline 1 & 4.26 & Top & 3.07 & 0.36 \\
\hline $\begin{array}{c}\text { PLIN } \\
\text { TH }\end{array}$ & 1.21 & Top & 0.32 & 0.03 \\
\hline FDN* & 0 & Top & 0 & 0 \\
\hline
\end{tabular}

*FDN-Foundation 


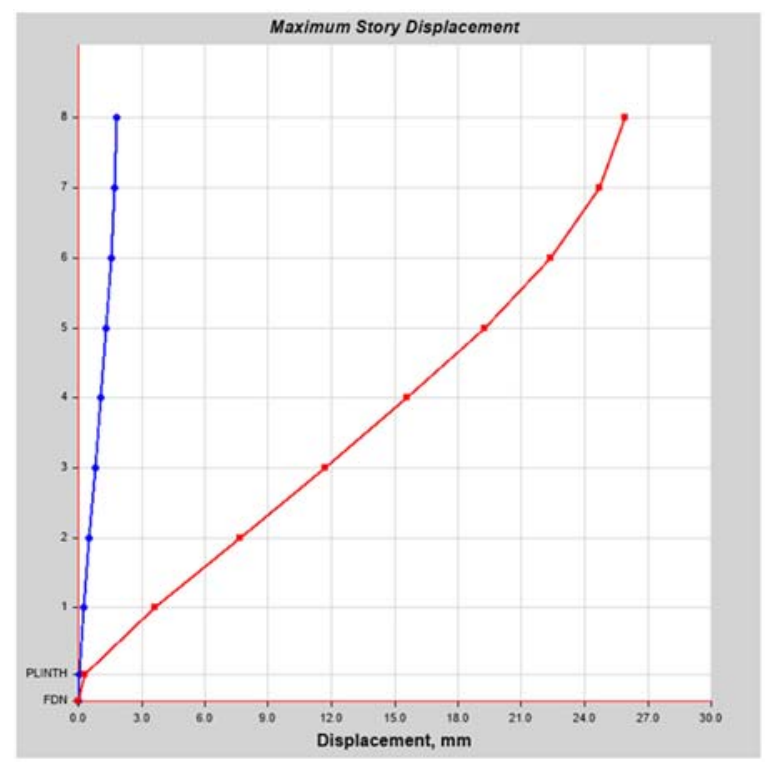

Figure-6: EQY Storey Displacements C-230x525 (C-50 25)

Table 10. Storey response values

\begin{tabular}{|c|c|c|c|c|}
\hline Storey & $\begin{array}{l}\text { Elevat } \\
\operatorname{ion}(m)\end{array}$ & Location & $\begin{array}{l}X- \\
\text { directio } \\
\text { n(mm) }\end{array}$ & $\begin{array}{l}Y- \\
\text { directio } \\
\text { n(mm) }\end{array}$ \\
\hline 8 & 26.67 & Top & 1.82 & 25.90 \\
\hline 7 & 23.46 & Top & 1.72 & 24.71 \\
\hline 6 & 20.26 & Top & 1.54 & 22.38 \\
\hline 5 & 17.06 & Top & 1.32 & 19.24 \\
\hline 4 & 13.86 & Top & 1.06 & 15.60 \\
\hline 3 & 10.66 & Top & 0.78 & 11.67 \\
\hline 2 & 7.54 & Top & 0.50 & 7.64 \\
\hline 1 & 4.26 & Top & 0.23 & 3.63 \\
\hline $\begin{array}{c}\text { PLIN } \\
\text { TH }\end{array}$ & 1.21 & Top & 0.02 & 0.29 \\
\hline FDN* & 0 & Top & 0 & 0 \\
\hline
\end{tabular}

*FDN-Foundation

\section{Future scope of the study}

The scope of the project is limited to reinforced concrete framed structures designed for dead loads (DL), live loads (LL), wind loads (WL) \& seismic loads (EL). The structure is evaluated in accordance with the codal provisions. The analysis done for storey structure is analyzed for different grades of concrete for beams and columns. The same building is analyzed and designed for different values of concrete strengths M25, M30, M40, M50. Furthre we can study the economical aspects of various multi-storied buildings by different grades of concrete. We can save both concrete material \& reinforcement steel.

\section{Conclusions}

We can see there is a significant reduction in terms of lateral storey displacements and cross-sectional sizes. If we compare the results of M25 C230x600 with the M50 C230x525 case there is a significant reduction in cross-section size for an approximate equivalent lateral displacement. Further, we can calculate the economic value of the reduction of cross-section sizes with varying different grades of concrete.

\section{References}

1. CSI (2017) ETABS 2017 Integrated Building Design Software, Version 16.0.2. Computers and Structures, Inc., Berkeley.

2. IS 13920 (1993) Ductile detailing of reinforced concrete structures subjected to seismic forcescode of practice. Bureau of Indian Standards, New Delhi.

3. IS 13920 (2016) Ductile design and detailing of reinforced concrete structures subjected to seismic forces-code of practice. Bureau of Indian Standards, New Delhi.

4. IS 1893 Part 1 (2002) Indian standard criteria for earthquake resistant design of structures, part 1: general provisions and buildings (fifth revision). Bureau of Indian Standards, New Delhi.

5. IS 1893 Part 1 (2016) Indian standard criteria for earthquake resistant design of structures, part 1: general provisions and buildings (sixth revision). Bureau of Indian Standards, New Delhi.

6. IS 456 (2000) Indian standard-plain and reinforced concrete, code of practice. Bureau of Indian Standards, New Delhi.

7. IS 875 (Part 1) (1987) Indian standard - code of practice for design loads (other than earthquake) 
for buildings and structures (dead loads). Bureau of Indian Standards, New Delhi.

8. IS 875 (Part 2) (1987) Indian standard - code of practice for design loads (other than earthquake) for buildings and structures (live loads). Bureau of Indian Standards, New Delhi.

9. IS 875 (Part 3) (1987) Indian standard — code of practice for design loads (other than earthquake) for buildings and structures (live loads). Bureau of Indian Standards, New Delhi.

10. IS 875 (Part 3) (2015) Indian standard - code of practice for design loads (other than earthquake) for buildings and structures (live loads). Bureau of Indian Standards, New Delhi.

11. Surana, M., Singh, Y., \& Lang, D. H. (2018). Effect of strong-column weak-beam design provision on the seismic fragility of RC frame buildings. International Journal of Advanced Structural Engineering, 10(2), 131-141.

12. Adam, M. A., \& El-Mohr, M. A. K. (2002, May). Effect of using different concrete strengths for columns and beams on the behaviour of building frames. In 4th International Conference on Civil \& Architecture Engineering (Vol. 4). ICCAE Cairo.

13. Wibowo, A., Wilson, J. L., Lam, N. T., \& Gad, E. F. (2014). Drift capacity of lightly reinforced concrete columns. Australian Journal of Structural Engineering, 15(2), 131-150.

14. Raheem, S. E. A. (2013). Evaluation of Egyptian code provisions for seismic design of momentresisting-frame multi-story buildings. International Journal of Advanced Structural Engineering, 5(1), 1-18.

15. Tawfik, A. S., Badr, M. R., \& ElZanaty, A. (2014). Behavior and ductility of high-strength reinforced concrete frames. HBRC Journal, 10(2), 215-221.

16. Ramesh, V., \& Srikanth, K. (2020). Mechanical Properties and Mix Design of Geopolymer concrete-A review. In E3S Web of Conferences (Vol. 184, p. 01091). EDP Sciences.

17. Koniki, S., \& Prasad, D. R. (2019). Influence of hybrid fibres on strength and stress-strain behaviour of concrete under uni-axial stresses. Construction and Building Materials, 207, 238248.

18. Cotipalli, V., Srinivas, T., \& Varma, V. N. K. (2021, July). Study on storey shear and base shear for irregular $\mathrm{G}+3, \mathrm{G}+6$ structures in seismic zones II and III erected on all three soils. In AIP Conference Proceedings (Vol. 2358, No. 1, p. 090008). AIP Publishing LLC.

19. Gunturi, M., Ravichandran, P. T., Annadurai, R., \& Krishnan, K. D. (2014). Experimental study on strength properties of problematic soils with
RBI-81 stabiliser. International Journal of Civil \& Structural Engineering, 4(3), 441-449.

20. Koniki, Srikanth, and D. Ravi Prasad. "Mechanical properties and constitutive stressstrain behaviour of steel fiber reinforced concrete under uni-axial stresses." Journal of Building Pathology and Rehabilitation 4.1 (2019): 1-8.

21. T.Srinivas and M. Abinay Raj, Int. J. of Eng.and Adv. Tech. (IJEAT), ISSN: 2249 - 8958, Volume-8 Issue-6 (2019)

22. T.srinivas and P. Manoj Anand, Int. J. of Innov. Tech. and Explor. Eng.g (IJTTEE), ISSN: 22783075, Volume-8 Issue-12 (2019)

23. T.Srinivas and G. Sukesh Reddy, Int. J. of Eng.and Adv. Tech. (IJEAT), ISSN: $2249-$ 8958, Volume-9 Issue-1 (2019)

24. T.Srinivas and R. N. Koushik, Int. J. of Innov. Tech. and Explor. Eng.g (IJITEE), ISSN: 22783075, Volume-8 Issue-12 (2019), PP 112-117.

25. K. Sai Gopi, Dr. T. Srinivas and S. P. Raju V, E3S Web of Conferences ICMED 184, 01084GRIET, 28-29 February, https://doi.org/10.1051/e3sconf/2020184011084 (2020)

26. Jagannadha Kumar, M.V., Jagannadha Rao, K., Dean Kumar, B., Srinivasa Reddy, V., Int. J. of Civil Eng. and Tech., 9(7), pp. 1133-1141 (2018)

27. Ganta, J.K., Seshagiri Rao, M.V., Mousavi, S.S., Srinivasa Reddy, V., Bhojaraju, C., Structures 28, pp. 956-972 (2020)

28. Naidu, K.S.S.T., Rao, M.V.S., Reddy, V.S., Int. J. of Innov. Tech. and Explor. Eng.g (IJTTEE), 8(9 Special Issue 2), pp. 641-642 (2019)

29. Chandana Priya, C., Seshagiri Rao, M.V., Srinivasa Reddy, V., Int. J. of Civil Eng. and Tech., 9(11), pp. 2218-2225 (2018)

30. Satya Sai Trimurty Naidu, K., Seshagiri Rao, M.V., Srinivasa Reddy, V., Int. J. of Civil Eng. and Tech., 9(11), pp. 2383-2393 (2018)

31. Supriya, Y., Srinivasa Reddy, V., Seshagiri Rao, M.V., Shrihari, S., Int. J. of Rec. Tech. and Engi., 8(3), pp. 5381-5385 (2019)

32. Kotkunde, N., Krishna, G., Shenoy, S.K., Gupta, A.K., Singh, S.K. International Journal of Material Forming, 10 (2), pp. 255-266 (2017)

33. Govardhan, D., Kumar, A.C.S., Murti, K.G.K., Madhusudhan Reddy, G. Materials and Design, 36, pp. 206-214. (2012)

34. Kumar, P., Singhal, A., Mehta, S., Mittal, A. Journal of Real-Time Image Processing, 11 (1), pp. 93-109. (2016)

35. Raghunadha Reddy, T., Vishnu Vardhan, B., Vijayapal Reddy, P. International Journal of Applied Engineering Research, 11 (5), pp. 30923102 (2016)

36. Hussaini, S.M., Krishna, G., Gupta, A.K., Singh, 
S.K. Journal of Manufacturing Processes, 18, pp. 151-158 (2015)

37. Kumar, C. V., Parvez, M. A., \& Srinivas, T. (2020). Strength Behaviour of Blended SelfCured Concrete made with Cement by partial replacement of Supplementary Cementitious Materials (SCM's). In E3S Web of Conferences (Vol. 184, p. 01100). EDP Sciences.
38. Ramesh, V., \& Srikanth, K. (2020). Mechanical Properties and Mix Design of Geopolymer concrete-A review. In E3S Web of Conferences (Vol. 184, p. 01091). EDP Sciences. 